\title{
Thermal Design Calculations for LED Luminaires
}

\section{Mehmet Sait CENGIZ ${ }^{*}$}

${ }^{1}$ Technical Vocational School, Bitlis Eren University, BITLIS, TURKEY

\section{Abstract}

Energy saving is one of the realities showed down human beings' throat by rapidly wasting world resources in today's world. In this context, nowadays LED armatures are replacing conventional lighting armatures as new generation lighting armatures. However, these innovations bring about new problems. While these innovations increase efficiency, they reveal the engineering problems that need to be solved. The most important problem is the thermal problems of LED armatures. In this study, the cooler size of the LED armature was calculated. In addition, a design prepared in ANSYS program was compared with its simulation and it was seen that the calculated cooler dimension gave successful results considering the simulation.

\section{Key Words}

“LED, lighting, thermal design, efficiency” 


\section{INTRODUCTION}

LED light sources used with right devices and elements have many advantages compared to conventional lighting sources. The most important advantages are energy saving, small size, long life, resistance to cracking and vibration and its good performance in cold weather. In addition to these advantages and many other advantages, there are some difficulties restricting their production and use (Cengiz vd., 2017; Eren vd., 2017).). The most important difficulty is the thermal problems of LED armatures (Palta vd., 2017).

LEDs generate heat, it is the heat of the electrical energy that cannot be converted into light. The heat is transmitted to the body of the armature over the LED itself. In addition, the heat generated on the power supply (LED driver) increases the heat in the armatüre (Cengiz vd., 2017). LED light sources are heat sensitive, so when they exceed the nominal heat values, heat based damage is seen in the LED lamp. The coolers on the LED lamps are designed to vent the heat generated on the LED by air (Ylldırım vd., 2017). This is the warmest part of the lamp and its aim is to keep the LED power supply and the electronic part as cool as possible. As a result, LED armature manufacturers have to design heat control systems and keep this implicit heat away from the armature for performance and long- life support of products.

Thermal control precautions cause increase in the size of the armature. Insufficient thermal control can cause colour shift, reduced light output and short life scan of the product. Time, market and developing technologies make thermal control easier in the design of armatures (Cengiz vd., 2017). The efficiency of LEDs is increasing gradually, more electricity is converted to luminous energy, and lost energy, in other words undesired heat production is reduced. However, thermal control is an important necessity. Thermal control provides advantages such as efficient use of LED products, and working LED with low and controlled current. Lower LED current means less undesired heat.

Heat management in LED armatures is the most important design problem. The efficient thermal management required in LED armatures requires the use of air ducts and strong body materials, which causes increase in the size of armatures.

No matter what happens, the efficiency and life of LED armatures are determined by operation and environmental temperatures. Naturally a LED armature to be used in hot climates and cold climates should be designed differently. For example, an armature designed for cold climates cannot show the same performance in hot climate. According to this approach, the cooler design should be done considering the climate and night temperatures of each zone.

\section{LED ARMATURE DESIGN PROCESS}

Combination of multiple LED dies creates LED package, combination of more than one LED package on a printed circuit board creates a LED module or a LED array, and a lighting unit generated when it is connected to a lighting armature with LED light sources, optical systems, cooler, and a power supply is called an integrated LED lamp [5].

In designing a LED armature, two different ways can be followed, such as designing a LED armature or designing a LED light source and placing it in an existing armature. It is expected that the efficiency of a new armature where only the LED light source is used is higher than the efficiency of placing LED light sources in the existing armatüre (Yapıcı vd., 2017). Because in the new design, the electrical, optical and thermal performances of LEDs can be taken into consideration. On the other hand, the armature design created by placing LED light source in an armature properly might be less efficient because it is generated according to another light source used before (Yurci vd., 2017).

\section{THERMAL PERFORMANCE-EFFICIENCY RELATIONSHIP}

Transfer of the heat generated within LED light source lighting armatures outside differs from other light sources. Many of the LED light source armature designs are still performed on the basis of the known radiation because conventional light sources transfer heat generated through radiation. LEDs can only transfer the heat they produce outside through transmission. This difference reveals the necessity to consider different heat transfer options when designing systems to work with LEDs. According to Figure 1, a $100 \mathrm{~W}$ LED armature is capable of generating $40 \mathrm{~W}$ light, but it is generated with $60 \mathrm{~W}$ of heat conduction and transmission. In addition, incandescent and fluorescent lamps, this situation happens with transmission to $8 \mathrm{~W}$ and $21 \mathrm{~W}$ light. Figure 1 compares the heat transfer mechanisms of light sources (Petroski. 2006). 


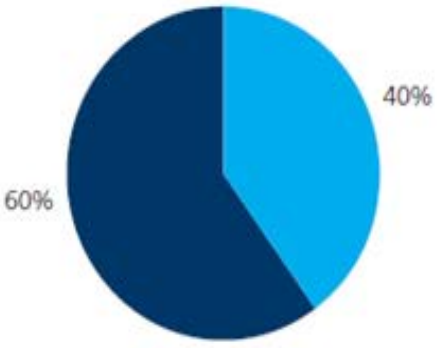

High Brightness LED

Visible light

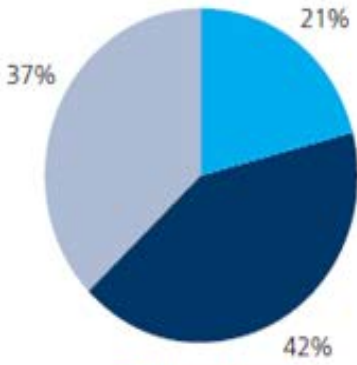

Fluorescent

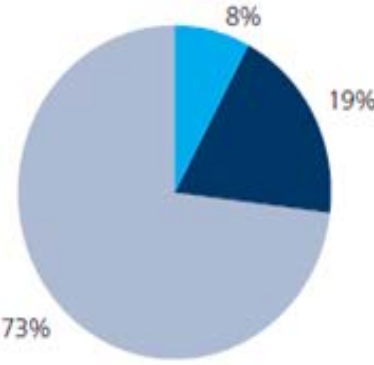

Incandescent

Heat removed by thermal radiation

Figure 1. Comparison of the heat transfer mechanisms of light sources

The approximate energy conversion table for various type of lamps is shown in Table 1.

Table 1. Approximate energy conversion table for various type of lamps

\begin{tabular}{|c|c|c|c|c|c|}
\hline Işık Kaynağı & Işınım (W) & Taşınım (W) & İletim (W) & Işık (W) & Toplam Güç (W) \\
\hline Enkandesen & 73 & $\sim 5$ & $\sim 5$ & 8 & 100 \\
\hline Florasan & 37 & 28 & 14 & 21 & 100 \\
\hline LED & $\sim 5$ & $\sim 5$ & 50 & 40 & 100 \\
\hline
\end{tabular}

Figure 1 and Table 1 show the necessity of generating the heat on LED armatures by using engineering calculations as most of the energy on LEDs is emitted by thermal conduction compared to the incandescent and fluorescent lamps. Considering that 100 $\mathrm{W}$ LED lamp has an average junction temperature of $100{ }^{\circ} \mathrm{C}$, the light efficiency drops from $40 \mathrm{~W}$ to $32 \mathrm{~W}$. Table 2 shows comparison of heat transfer and heat efficiency when the junction temperature is $100{ }^{\circ} \mathrm{C}$ and higher.

Table 2. Comparison of total heat transfers and light efficiency

\begin{tabular}{|c|c|c|c|}
\hline Işıı Kaynağı & Isı (W) & Işık (W) & Toplam Güç (W) \\
\hline Enkandesen & 92 & 8 & 100 \\
\hline Florasan & 79 & 21 & 100 \\
\hline LED & 68 & 32 & 100 \\
\hline
\end{tabular}

According to Table 2, while we have a heater of $90 \mathrm{~W}$ in an incandescent lamp of $100 \mathrm{~W}$, LED armature has a heater of 68W. However, due to the heat discharge method, the armature body is warmer in LED armatures. Thus, compared to conventional armatures, the light efficiency of LED armatures decreases due to the transmission based thermal problems. So increasing temperature reduces the light. Therefore, thermal control and engineering calculations are necessary for LEDs.

As the junction temperature of the LEDs increases, the amount of light they produce decreases. Figure 2 shows the change in light fluxes of LEDs emitting light in different colors for different junction temperatures. It is accepted that the maximum light flux is obtained at $25^{\circ} \mathrm{C}$. As seen in Figure 2, as the temperature increases, the light flux drops significantly. Therefore, only when armature designs of LEDs are designed with catalog values, lower light flux can be achieved in actual use. In order to avoid these problems, in practice thermal behavior of the armature must be examined in detail (Petroski. 2006). 


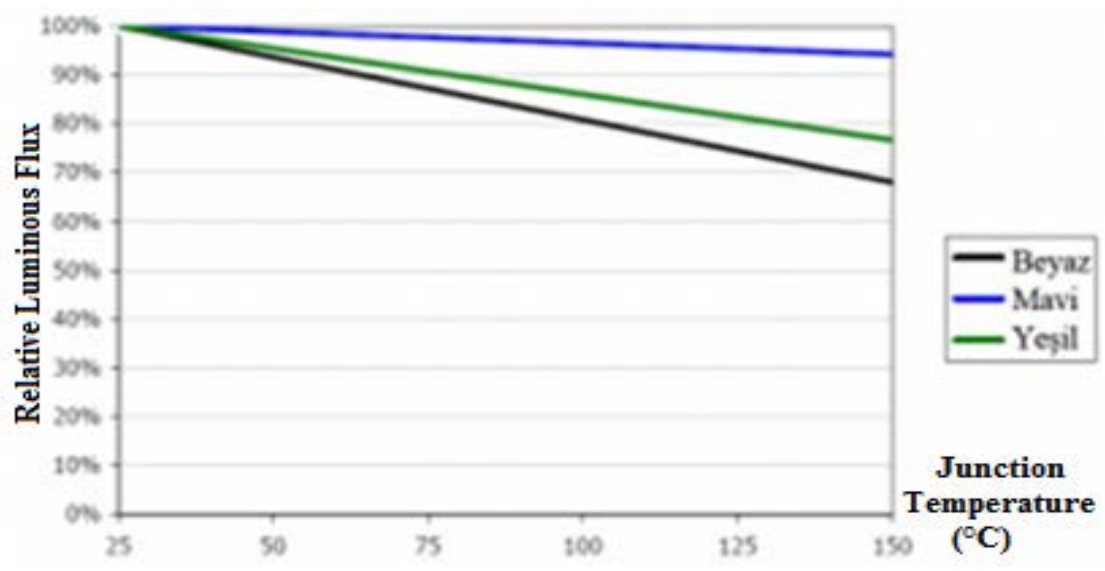

Figure 2. Effect of increasing junction temperature on the light flux (CREE, 2009)

There are many programs in the literature for thermal analysis of armatures. All programs can predict the temperature distribution and air movement within the armature by using such mathematical methods as finite elements, finite differences etc.

\section{CALCULATING THE SIZE OF COOLER}

Choosing a cooler in LED lighting applications is the most important parameter that affects the life of LEDs. LED coolers are used to prevent semiconductor based heat accumulation and to spread the accumulated heat to the surroundings. Aluminium is usually used for this purpose. Aluminium is preferred for all applications requiring heat transfer as it is a metal that easily cools and absorbs heat. Its density is about one third of steel or copper. It can be shaped easily and it is machinable. Its corrosion resistance is strong. It is a metal used in many sectors because it is cheaper than copper and is found more easily, and it is soft and machinable.

In the thermal resistance curve of the cooler, the required cooler length can be calculated by using the obtained $\mathrm{R}$ cooler. In the theoretical study, equivalent of the material in question can be seen by using the products of both the upper and lower value lengths in the value calculation. This material may be pure aluminium or any composite material which has been subjected to different ratios of mixture. Equations 1 and 2 are used in the calculation of cooler size.

$$
\begin{aligned}
& R_{\text {LED }}+R_{\text {thermal }}+R_{\text {cooler }} \leq R_{\text {system }}=\left(T_{j}-T_{0}\right) / P \\
& R_{\text {system }}=\left(T_{j}-T_{0}\right) / P
\end{aligned}
$$

\subsection{Example of A Cooler Designed}

In this case study, calculations regarding the thermal-size relationship of a LED lighting armature of $90 \mathrm{~W}$ will be calculated. The thermal resistance for the thermal paste used is $3.8 \mathrm{~K} / \mathrm{W}$. 40 LEDs are used in the armature.

P (System Power): 90 Watt (When 40 LED armature is driven with $700 \mathrm{~mA}$ )

$\mathrm{T}_{\mathrm{o}}: 25^{\circ} \mathrm{C}$ (maximum temperature at night)

$\mathrm{Tj}: 98^{\circ} \mathrm{C}$ (junction temperature)

The junction temperature is $128^{\circ} \mathrm{C}$. Due to the safety factor, a $30^{\circ} \mathrm{C}$ lower rate should be used in the calculations.

If substituted in equation 2;

$$
\begin{aligned}
& R_{\text {system }}=(98-25) / 90 \\
& R_{\text {system }}=0.811 \mathrm{~K} / \mathrm{W} \\
& R_{L E D}=3.8 / 40=0.095 \mathrm{~K} / \mathrm{W} \\
& R_{\text {thermal }}=0.07 \mathrm{~K} / \mathrm{W}
\end{aligned}
$$

( $0.07 \mathrm{~K} / \mathrm{W}$, It was taken from the datasheet of the thermal paste used)

If substituted in equation 1 ; 


$$
\begin{aligned}
& 0.81 \geq R_{\text {cooler }}+0.095+0.07 \\
& R_{\text {cooler }} \leq 0.645 \mathrm{~K} / \mathrm{W}
\end{aligned}
$$

According to this calculation, the size of the cooler to be selected for the value of $R_{\text {cooler }} \leq 0.645 \mathrm{~K} / \mathrm{W}$ is selected from the graphic of PR-79 standard in the thermal resistance curve for Al shown in Fig. 1. The cooler size of the LED lamp in question corresponds to a size of $200 \mathrm{~mm}$. Accordingly, the size of the cooler to be selected is $200 \mathrm{~mm}$. Figure 3 shows the thermal resistance curve PR-79 (LED Academy, 2015).

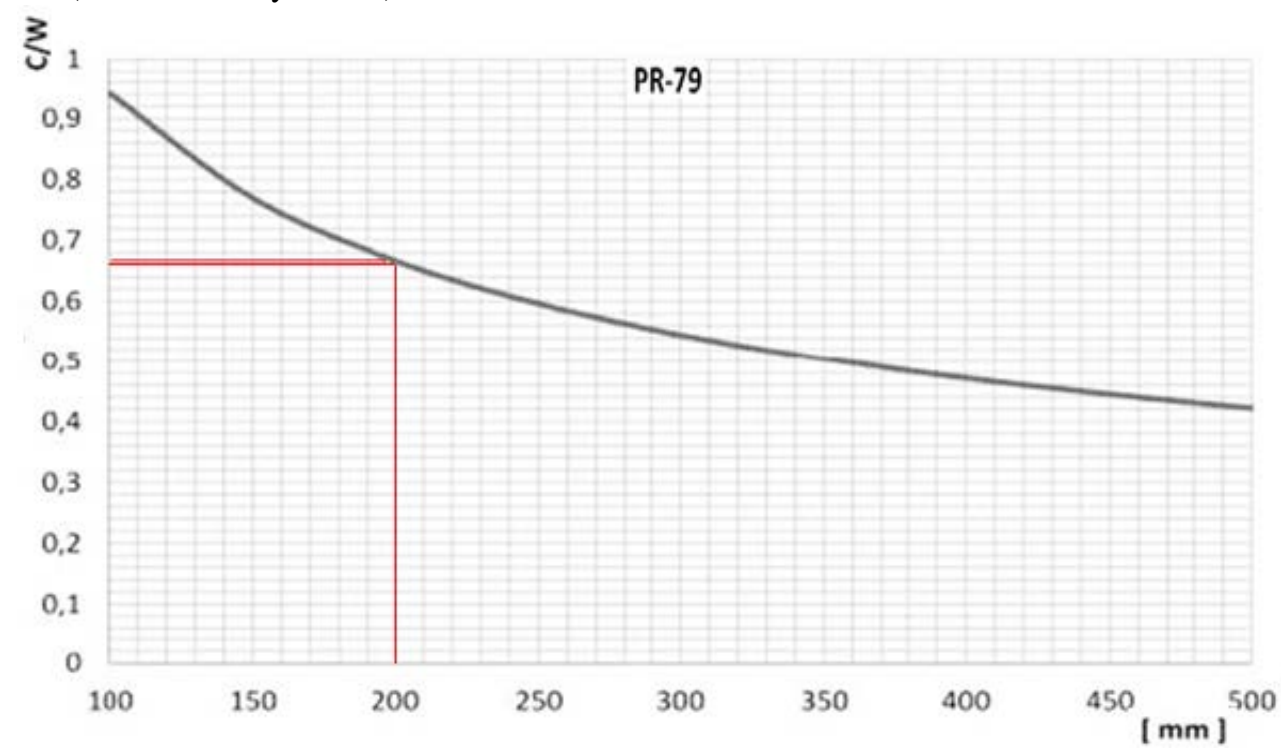

Figure 3. Thermal resistance curve PR-79

In a study, virtual prototype of a LED armature was produced in computer environment by using ANSYS software. The LED armature design of which was simulated in the ANSYS program and with a cooler size of $200 \mathrm{~mm}$ is shown in Figure 4 . The shared results belong to a LED armature with $200 \mathrm{~mm}$ cooler surface. Figure 5 shows the thermal state of a LED armature with a $200 \mathrm{~mm}$ cooler (Yıldırım vd., 2016)

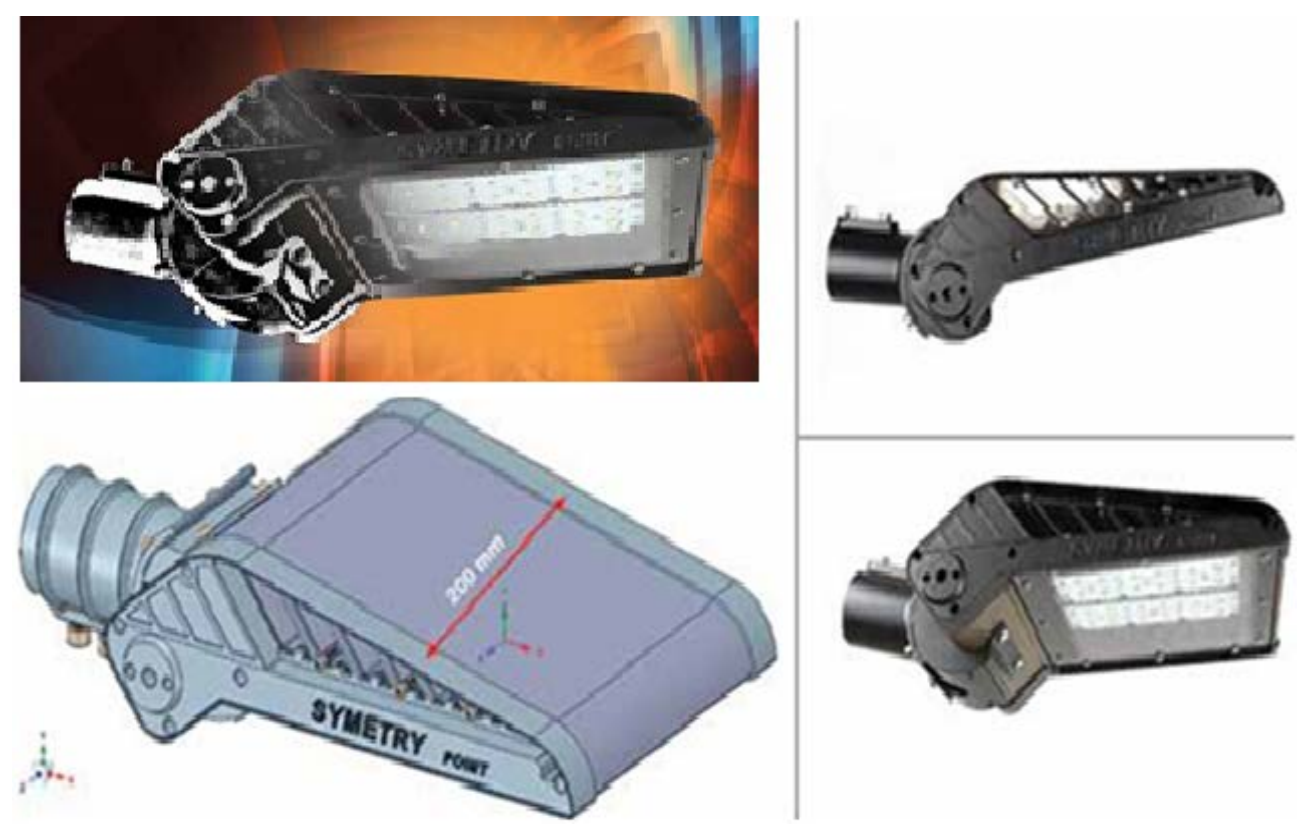

Figure 4. A LED armature with $200 \mathrm{~mm}$ cooler 


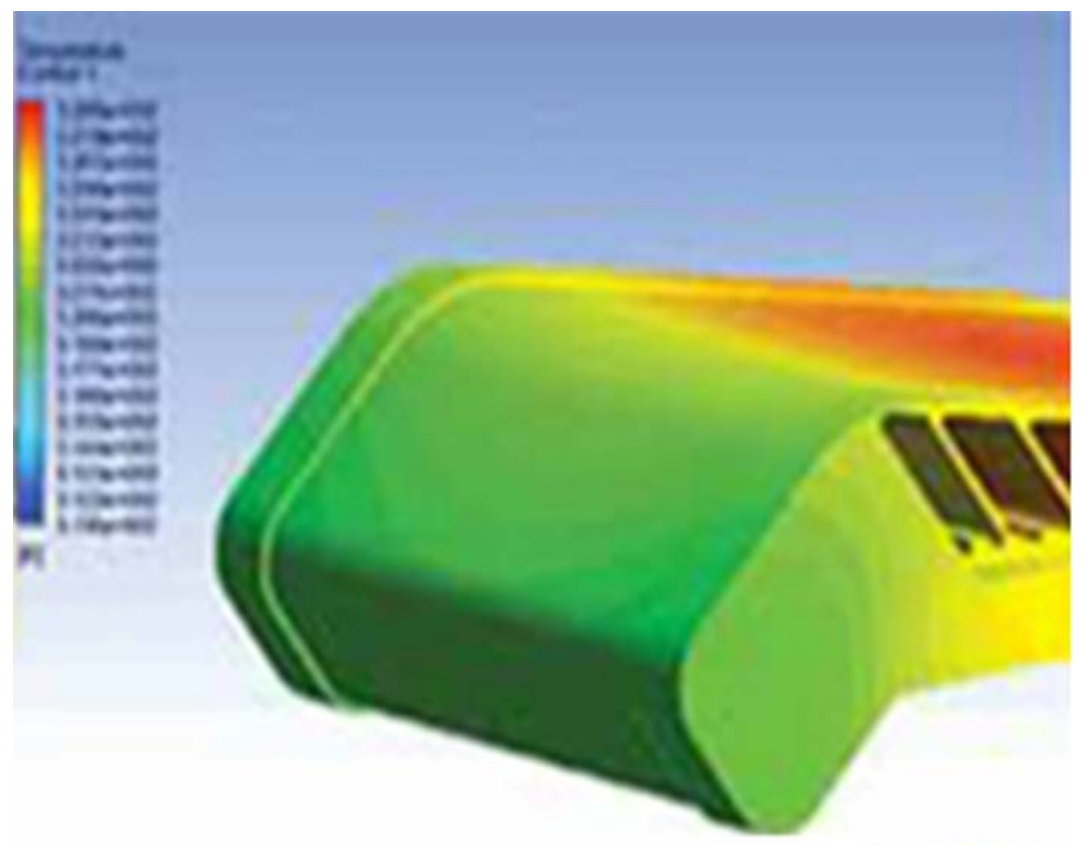

Figure 5. Thermal state of a LED armature with $200 \mathrm{~mm}$ cooler

\section{CONCLUSION}

As the size of the armature grows, the heat transfer surface area on the exterior area also grows. According to the achieved thermal analysis, armatures of $200 \mathrm{~mm}$ were found to provide the required cooling performance. It is understood that larger armatures are unnecessarily large.

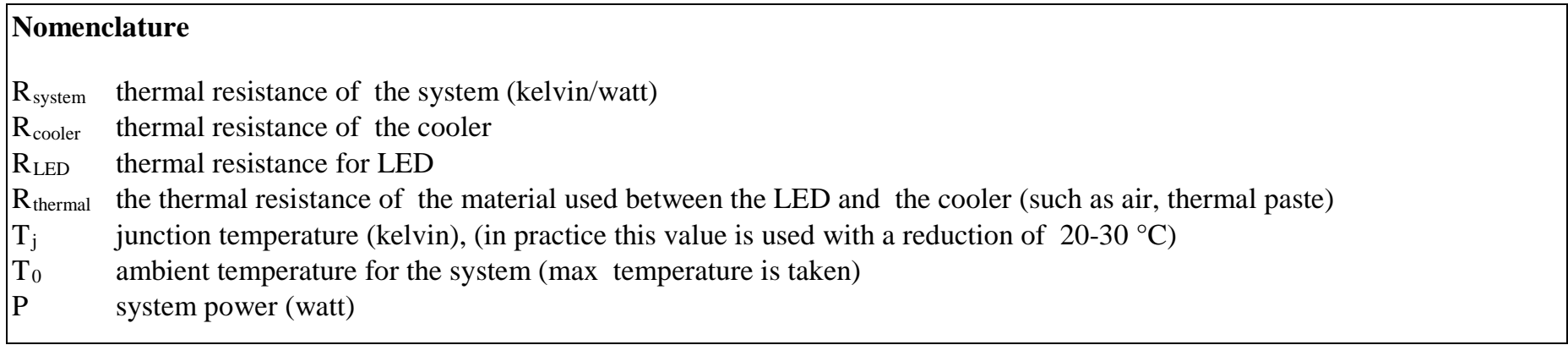

\section{REFERENCES}

Cengiz Ç., Cengiz M.S., Yurci Y., Kaynaklı M., Parlakyıldız Ş., İlcihan Z., (2017) Realization of warming in LED lighting, Journal of Electrical and Electronics Engineering (IOSR-JEEE), 12(6), 83-85.

Cengiz Ç., Kaynaklı M., Gencer G., Eren M., Yapici İ., Yildirim S., Cengiz MS., Selection Criteria and Economic Analysis of LEDs, International Conference on Multidisciplinary, Science, Engineering and Technology Bitlis Book of Abstracts, October 27-29, 2017, Bitlis

Cengiz M.S., Eren M., Cengiz Ç., Yıldırım S., Yapıcı İ., Yurci Y., Atiç S, Palta O., Numerical analysis of warming and warming problem in LED lamps. Imeset International Conference Baku Book of Abstracts, 12-14 July 2017, Baku.

CREE, SSL Design Processes/Considerations, 2009. Available from:www.cree.com ABD, (Accessed 09.09.2017). 
Eren M., Yapıcı İ., Yıldırım S., Cengiz Ç., Gencer G., Palta O., Aybay E., Yurci Y., (2017) Driver Circuit Effects in LED Lighting Systems, Realization of warming in LED lighting, Journal of Electrical and Electronics Engineering (IOSR-JEEE), 12(6), vers. III.

Gencer G., Eren M., Yildirim S., Kaynaklı M., Palta O., Cengiz M.S., Cengiz Ç., Numerical Approach to City Road Lighting Standards, International Conference on Multidisciplinary, Science, Engineering and Technology, October 27-29, 2017, Bitlis

LED Academy, (2015) Available from: http://www.ledacademy.net/wp-content/uploads/2015/03/lesson3.pdf, (Accessed 10.10.2017)

Palta O., Yıldırım S., Yapıcı İ., Eren M., İlcihan Z., Aybay E., Gencer G., (2017) Cost Comparison in LED Lighting and Selection Criteria in LEDs, Journal of Electrical and Electronics Engineering (IOSR-JEEE), 12(6), vers. III.

Petroski J., (2006) Thermal challenges in LED cooling, Available from:www.electronicscooling.com/2006/11/thermalchallenges-in-led-cooling/ (Accessed 10.10.2017).

Yapici I., Eren M., Gencer G., Yıldırım S., Cengiz Ç., Kaynaklı M., Cengiz M.S., Driver circuit effects in LED Lighting Systems, International Conference on Multidisciplinary, Science, Engineering and Technology Bitlis Book of Abstracts, October 27-29, 2017, Bitlis

Yıldırım A., Elmas N., Rezazad H., Karaismail E., (2016) LED aydınlatma armatürü termal analiz çalışmaları, Available from: http://www.grupimaj.com/led-aydinlatma-armaturu-termal-analiz-calismalari-sf26.html (Accessed 10.10.2017).

Yıldırım S., Yapıcı İ., Atiç S., Eren M., Palta O., Cengiz Ç., Cengiz M.S., Yurci Y., Numerical Analysis of Productivity and Redemption Periods in LED Illimunation. Imeset International Conference Baku Book of Abstracts, 12-14 July 2017, Baku.

Yurci Y., Cengiz Ç., Yapıcı İ., Cengiz MS., Yıldırım S., Eren M., Palta O., Atiç S., Analysis of energy productivity in LED illumination by active or passive methods. Imeset International Conference Baku Book of Abstracts, 12-14 July 2017, Baku. 